\title{
The cdc30 Mutation in Saccharomyces cerevisiae Affects Phosphoglucose Isomerase, the Cell Cycle and Sporulation
}

\author{
By J. RICHARD DICKINSON,* MAXINE E. SMITH, \\ TIMOTHY R. SWANSON, ANTHONY S. WILLIAMS AND \\ JONATHAN M. WINGFIELD \\ Department of Microbiology, University College Cardiff, Newport Road, Cardiff, CF2 ITA, UK
}

(Received 16 February 1988; revised 10 May 1988)

\begin{abstract}
Spontaneous revertants of the $c d c 30$ mutation in Saccharomyces cerevisiae simultaneously regained the ability to grow and divide at $36.5{ }^{\circ} \mathrm{C}$ on glucose-containing media along with a more thermostable phosphoglucose isomerase (PGI). An independently isolated allele of $c d c 30$ gave a similar phenotype to that previously described including temperature-sensitivity of PGI. Isoelectric focussing allowed the separation of two isoenzymes of PGI. These results all support the idea that two genes - PGII and CDC 30 - are responsible for PGI activity in yeast. Diploid strains homozygous for the $c d c 30$ mutation sporulated poorly in potassium acetate irrespective of whether the cells had previously been cultured at a temperature that was permissive or restrictive for cell cycle progression. This was not surprising because a strain defective in PGI would not be expected to be able to complete the gluconeogenic events of sporulation.
\end{abstract}

\section{INTRODUCTION}

Control of the cell cycle and cell development are unsolved problems in biology. In the yeast Saccharomyces cerevisiae the isolation and study of cell division cycle $(c d c)$ mutants has provided much genetic and physiological information. Biochemical understanding of regulation and control of the cell cycle has lagged behind genetic and physiological descriptions because the identities of the products of most $C D C$ (wild-type) genes remain unknown. However the following gene/enzyme relationships have been established: $C D C 7$ - protein kinase (Patterson et al., 1986); CDC8 - thymidylate kinase (Jong et al., 1984; Sclafani \& Fangman, 1984); CDC9DNA ligase (Johnston \& Nasmyth, 1978; Barker et al., 1985); CDC19 - pyruvate kinase (Kawasaki, 1979); CDC21 - thymidylate synthetase (Game, 1976); CDC28 - protein kinase (Reed et al., 1985); CDC30 - high $K_{\mathrm{m}}$ ('isoenzyme I') PGI (Dickinson \& Williams, 1987); and CDC35 - adenylate cyclase (Mason et al., 1984; Casperson et al., 1985).

We realized that our view that PGI activity in $S$. cerevisae requires the products of both the $C D C 30$ and the $P G I 1$ genes (Dickinson \& Williams, 1987) differs from that of several other workers who have shown that mutation in the single nuclear gene PGII (Clifton et al., 1978; Herrera \& Pascual, 1978; Ciriacy \& Breitenbach, 1979; Maitra, 1971; Maitra \& Lobo, 1977) or that deletion of the $P G I I$ gene (which had been isolated by complementation of a pgil mutation) (Aguilera, 1986) gives a complete phenotype, although earlier work of a purely biochemical nature had shown that yeast has three isoenzymes of PGI which differ in net charge but not in $M_{\mathrm{r}}$ (Nakagawa \& Noltmann, 1967; Kempe et al., 1974a,b).

In order to confirm that the $C D C 30$ gene encodes isoenzyme I of PGI we isolated revertants of $c d c 30$ for further study. We analysed the PGI isoenzyme complement of wild-type and $c d c 30$ mutant strains using isoelectric focussing gels. This report also describes a strain carrying a newly isolated allele of $c d c 30$ and the effect of the $c d c 30$ mutation on sporulation in yeast.

Abbreviation: PGI, phosphoglucose isomerase.

0001-4709 (C) 1988 SGM 


\section{J. R. DICKINSON AND OTHERS}

Table 1. Genotypes and origins of strains used

Strain

A364A MATa adel ade2 ural his7 lys2 tyrl gall

23015 MATa adel ade2 ural his7 lys2 tyr1 gall cdc30-I

$59.4 \mathrm{~A}$

$\frac{M A T \mathrm{a}}{M A T \alpha} \frac{H O}{H O} \frac{\arg 4-1}{\arg 4-1} \frac{\text { cyhl }}{\text { cyhl } 1} \frac{\text { spdl }}{\text { spdl }}$

JPT99

MATa $c d c 30-3$

WD1

$\frac{M A T \mathrm{a}}{M A T \alpha} \frac{\arg 4-1}{A R G 4-1} \frac{U R A 3}{\text { ura3 }} \frac{C D C 30-3}{c d c 30-3}$

WD2

$\frac{M A T a}{M A T \alpha} \frac{\text { adel }}{A D E 1} \frac{\text { ade2 }}{A D E 2} \frac{\text { ural }}{U R A 1} \frac{\text { his7 }}{H I S 7} \frac{\text { lys2 }}{\text { LYS2 }} \frac{\text { tyr1 }}{\text { TYR1 }} \frac{\text { gall }}{\text { GAL1 }} \frac{\text { URA3 }}{\text { ura3 }} \frac{\text { cdc30-1 }}{\text { cdc30-3 }}$

$\frac{M A T \mathrm{a}}{M A T \alpha} \frac{\arg 4-1}{A R G 4-1} \frac{H I S 3}{\text { his3 }} \frac{\text { LEU2 }}{\text { leu2 }} \frac{U R A 3}{\text { ura3 }} \frac{\text { TRP1 }}{\text { trpl }} \frac{\text { cdc30-3 }}{\text { CDC30-3 }}$

WD3

WD4

$\frac{M A T \mathrm{a}}{M A T \alpha} \frac{\arg 4-1}{A R G 4-1} \frac{H I S 3}{\text { his3 }} \frac{\text { LEU2 }}{\text { leu2 }} \frac{\text { URA3 }}{\text { ura3 }} \frac{\text { TRP1 }}{\text { trp1 }}$

WD6
Origin*

YGSC

YGSC

I. Dawes

J. Pringle

This work

This work

This work

This work

This work

* YGSC, Yeast Genetic Stock Center, Berkeley, California, USA; I. Dawes, University of Edinburgh, UK; J. Pringle, University of Michigan, Ann Arbor, Michigan, USA.

\section{METHODS}

Strains, growth conditions and genetic procedures. The strains used are described in Table 1. Cells were grown with shaking in conical flasks filled to $40 \%$ total volume in YEPD medium, which comprised $1 \%(\mathrm{w} / \mathrm{v})$ yeast extract, $2 \%(\mathrm{w} / \mathrm{v})$ peptone, $2 \%(\mathrm{w} / \mathrm{v})$ glucose and $0.01 \%(\mathrm{w} / \mathrm{v})$ of both adenine and uracil. Standard genetic techniques were used (Sherman, 1975; Mortimer \& Hawthorne, 1975). To study the effect(s) of $c d c 30$ mutations on sporulation cells were grown in YEPD medium at $25^{\circ} \mathrm{C}$ to mid exponential phase. Each culture was then divided into three equal portions. Portion ' $\mathrm{a}$ ' was incubated for $2.5 \mathrm{~h}$ at $25^{\circ} \mathrm{C}$ when the cells were harvested by centrifugation and transferred to sporulation medium $\left(2 \%\right.$, w/v, potassium acetate). Portion 'b' was incubated at $36 \cdot 5^{\circ} \mathrm{C}$ for $5 \mathrm{~h}$, by which time all cells bearing the temperature-sensitive $c d c 30$ mutation will have cell cycle arrested (Dickinson $\&$ Williams, 1987), and then transferred to sporulation medium in the same way as portion ' $a$ '. Portion ' $c$ ' was incubated at $25^{\circ} \mathrm{C}$ for $2.5 \mathrm{~h}$ after which time the cells were harvested by centrifugation and resuspended in fresh YEPD medium. These cells were incubated at $30^{\circ} \mathrm{C}$ for a further $6 \mathrm{~h}$ during which period samples were removed and fixed in formalin/saline $(40 \%, \mathrm{w} / \mathrm{v}$, formaldehyde $/ 1 \%, \mathrm{w} / \mathrm{v}, \mathrm{NaCl} ; 0.5: 100, \mathrm{v} / \mathrm{v})$ for subsequent cell counting using a Coulter counter. Cells were incubated in sporulation medium at $30^{\circ} \mathrm{C}$ for $48 \mathrm{~h}$ after which time sporulation was assessed by scoring at least 400 cells. The permissive temperature for the $c d c 30$ mutants is $25^{\circ} \mathrm{C}$, hence portion ' $\mathrm{a}$ ' is a control. Portion ' $c$ ' is also a control to check whether the temperature of $30^{\circ} \mathrm{C}$ used to induce sporulation causes cell cycle arrest in $c d c 30$ mutants: it does not (J. R. Dickinson \& A. S. Williams, unpublished result).

Isolation of revertants. The $c d c 30$ mutation is expressed on YEPD medium at $36.5^{\circ} \mathrm{C}$ but not at $25^{\circ} \mathrm{C}$. Spontaneous revertants of 23015 were obtained by plating cells on YEPD at $36.5^{\circ} \mathrm{C}$. After $4-5 \mathrm{~d}$ papillae were present. These were collected, checked for clonal purity and retested.

Assay of PGI activity. Cell extracts were prepared and enzyme activity determined as described previously (Dickinson \& Williams, 1987). In experiments to determine the effect of heating on PGI activity cell extracts were heated and shaken rapidly in a water-bath at $55^{\circ} \mathrm{C}$ with vigorous vortexing at 0,30 and 60 min before being used immediately in the assay.

Isoelectric focussing. Cell extracts prepared as described previously (Dickinson \& Williams, 1987) and containing $1 \%(\mathrm{w} / \mathrm{v})$ phenylmethylsulphonyl fluoride to prevent proteolytic breakdown were analysed on ultrathin polyacrylamide gels. The gels were cast according to the method of Caswell et al. (1986), and were composed of $5 \%(\mathrm{w} / \mathrm{v})$ acrylamide, $0.17 \%(\mathrm{w} / \mathrm{v}) N, N^{\prime}$-methylene bisacrylamide, $20 \%(\mathrm{v} / \mathrm{v})$ glycerol, $10 \mu 1 \mathrm{~N}, N, N^{\prime} N^{\prime}$ tetramethylethylenediamine (TEMED), $5 \%(\mathrm{w} / \mathrm{v})$ carrier ampholytes $(\mathrm{pH}$ range $3-10)$ and $0.038 \%$ ammonium persulphate, made up to a final volume of $10 \mathrm{ml}$. Prefocussing was at $2 \mathrm{~W}$ for $30 \mathrm{~min}$ and focussing was at $4.5 \mathrm{~W}$ constant power or $2 \mathrm{kV}$ maximum voltage for $170 \mathrm{~min}$. Gels were stained using PAGE blue G-90 (BDH) as described by Blakesley \& Boezi (1977). Quantification was achieved using a LKB 2202 Ultroscan laser densitometer and Ultrascan computer program. Purified yeast PGI of known concentration was used for calibration. 
Table 2. Effect of heat treatment on PGI activity

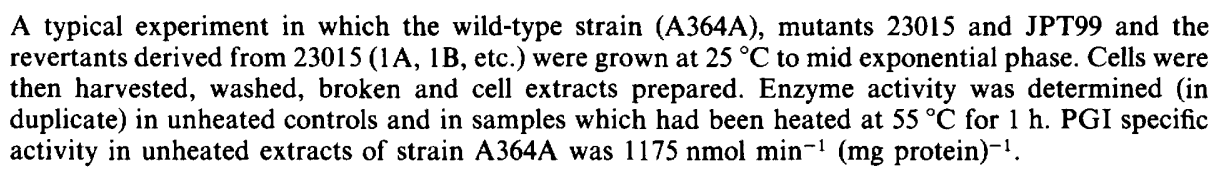

$\begin{array}{lccc}\text { Strain } & \begin{array}{c}\text { PGI activity remaining } \\ \text { after heat treatment }(\%)\end{array} & \text { Strain } & \begin{array}{c}\text { PGI activity remaining } \\ \text { after heat treatment }(\%)\end{array} \\ \text { A364A } & 29.97 & 1 \mathrm{G} & 22 \cdot 21 \\ \text { 23015 } & 0 \cdot 0 & 2 \mathrm{~A} & 17 \cdot 89 \\ \text { JPT99 } & 0 \cdot 0 & 2 \mathrm{~B} & 7 \cdot 10 \\ \text { 1A } & 28 \cdot 17 & 4 \mathrm{G} & 14 \cdot 48 \\ \text { 1B } & 24.90 & 6 \mathrm{~A} & 9.87 \\ \text { 1C } & 32.69 & 6 \mathrm{G} & 19 \cdot 90 \\ \text { 1D } & 17.99 & 7 \mathrm{G} & 14 \cdot 84 \\ \text { IE } & 32.94 & 8 \mathrm{~B} & 31 \cdot 14 \\ \text { IF } & 19 \cdot 83 & 8 \mathrm{C} & 4.25\end{array}$

\section{RESULTS AND DISCUSSION}

Revertants of 23015 have recovered PGI activity

We obtained 51 spontaneous revertants of 23015 which were able to grow and divide at $36.5^{\circ} \mathrm{C}$. In order to test between intragenic and extragenic reversion events outcrosses were made to spores of the homothallic strain 59.4A and the resulting diploids sporulated. Analysis of the spore progeny merely required inspection for $c d c 30$-bearing (YEPD-negative at $36.5^{\circ} \mathrm{C}$ ) clones. These could only arise from strains carrying the original $c d c 30$ mutation and an extragenic suppressor. The majority (18 out of 21 examined) were the result of intragenic reversion events (i.e. no $c d c 30$-bearing clones recovered from the cross described).

The $c d c 30$ mutation in strain 23015 results in a thermolabile PGI which is unable to survive the heating regime (Table 2). In the wild-type (A364A) approximately $30 \%$ of the PGI activity remained after the heat treatment. PGI activity from all of the revertants was more thermostable than that from strain 23015, and in two cases (revertants $1 \mathrm{C}$ and $1 \mathrm{E}$ ) even more stable than that from the original wild-type parent. This experiment used a more aggressive heat-treatment than the one described previously (Dickinson \& Williams, 1987), as it simultaneously highlights thermolability and simplifies the handling of extracts from a larger number of strains. These results are consistent with the idea that the $C D C 30$ gene codes for isoenzyme I of PGI.

Table 2 also shows that the independently isolated strain JPT99 has a temperature-sensitive PGI. The mutation in this strain had been tentatively assigned as $c d c 30$ by the Michigan group on the basis of failure to complement a $c d c 30-1$ mutation. We confirmed this result and observed that the mutation in strain JPT99 behaved like the $c d c 30-1$ allele in crosses. Furthermore, strain JPT99 and the progeny derived therefrom were like strain 23015 in that they were all capable of growth and cell division at $36.5^{\circ} \mathrm{C}$ on non-fermentable carbon sources. On the basis of these criteria we feel confident in assigning the mutation present in strain JPT99 as ' $c d c 30-3^{\prime}$ ', for, to our knowledge, this is only the third allele of $c d c 30$ that has been described. To be consistent with convention ' $c d c 30$ ' should be re-named 'pgi2', hence this new allele of $c d c 30$ ought to be called 'pgi2-3'.

\section{Physical separation of PGI isoenzymes I and II}

Fig. 1 shows that isoelectric focussing physically resolved isoenzymes I and II of PGI which had been deduced previously from kinetic data (Dickinson \& Williams, 1987). From Table 3 it is clear that the wild-type and mutant strains contained similar amounts of isoenzyme II, but that the mutant strain 23015 contained only half the amount of isoenzyme I that was present in the wild-type. This result could be taken as evidence that $C D C 30$ is a regulator of the amount of PGI isoenzyme I rather than the structural gene, though this would contradict the majority of the 


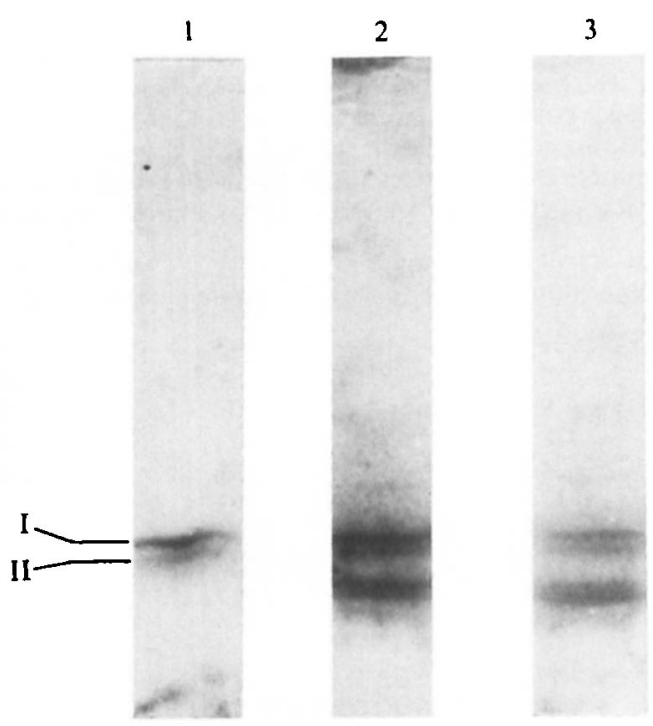

Fig. 1. Isoelectric focussing gel showing isoenzymes of PGI. Cells of the wild-type strain (A364A) and $c d c 30$-bearing mutant (23015) were grown to mid exponential phase at $25^{\circ} \mathrm{C}$. Cell extracts were then prepared and analysed as described in Methods. Lane 1, purified PGI; lane 2, extract from wild-type A364A; lane 3, extract from mutant strain 23015.

Table 3. Relative amounts of PGI isoenzymes I and II determined by scanning densitometry of isoelectric focussing gels

\begin{tabular}{|c|c|c|c|}
\hline \multirow[b]{2}{*}{ Source of PGI } & \multicolumn{2}{|c|}{$\begin{array}{l}\text { Relative amount of protein } \\
\text { in isoenzyme } \\
\text { (percentage of total protein) }\end{array}$} & \multirow{2}{*}{$\begin{array}{l}\text { Ratio } \\
\text { (I/II) }\end{array}$} \\
\hline & I & II & \\
\hline $\begin{array}{l}\text { Purified enzyme } \\
\text { A364A } \\
23015\end{array}$ & $\begin{array}{r}66.80 \pm 0.20 \\
6.86 \pm 0.68 \\
3.64 \pm 0.23\end{array}$ & $\begin{array}{r}33.20 \pm 0.20 \\
2.93 \pm 0.33 \\
3.15 \pm 0.22\end{array}$ & $\begin{array}{l}2 \cdot 01 \\
2 \cdot 34 \\
1 \cdot 15\end{array}$ \\
\hline
\end{tabular}

evidence presented earlier and in this report. Perhaps there is increased proteolysis of the mutant protein and we are currently examining this possibility using a range of protease mutants.

\section{Effect of cdc30 mutations on sporulation}

Simchen (1974) was the first to examine whether $c d c$ mutations affect sporulation. He divided cell cycle mutations into three classes depending upon their effect on sporulation (Simchen 1974): (i) mutations permitting normal sporulation; (ii) mutations giving no sporulation at the restrictive temperature but normal sporulation at the permissive temperature; and (iii) mutations producing no sporulation at either temperature. The results of many different investigations have been reviewed (Pringle \& Hartwell, 1981; Esposito \& Klapholz, 1981). We were interested to examine the effect of $c d c 30$ mutations on sporulation for three reasons. Firstly, because diploids can only switch from vegetative growth and mitosis to the alternative developmental pathway of meiosis and sporulation when in the G1 portion of the cell cycle whereas at $36.5^{\circ} \mathrm{C}$ the $c d c 30$ mutation causes arrest late in nuclear division. Secondly, because it is known that an intact sequence of gluconeogenic enzymes is required for sporulation 
Table 4. Effect of cdc30 mutations on sporulation

Cells were grown at $25^{\circ} \mathrm{C}$ to mid exponential phase. The cultures were then divided and the cells treated as indicated before being transferred to sporulation medium. The results are means \pm SEM of three experiments.

\begin{tabular}{|c|c|c|c|}
\hline \multirow[b]{2}{*}{ Strain } & \multirow[b]{2}{*}{$\begin{array}{l}\text { Relevant } \\
\text { genotype }\end{array}$} & \multicolumn{2}{|c|}{ Sporulation (percentage asci) } \\
\hline & & $\begin{array}{l}\text { After prior culture at } \\
25{ }^{\circ} \mathrm{C} \text { for } 2.5 \mathrm{~h}\end{array}$ & $\begin{array}{l}\text { After prior culture at } \\
36.5^{\circ} \mathrm{C} \text { for } 5 \mathrm{~h}\end{array}$ \\
\hline WD1 & $\frac{C D C 30-3}{c d c 30-3}$ & $71 \cdot 0 \pm 2 \cdot 5$ & $58 \cdot 2 \pm 3 \cdot 9$ \\
\hline WD2 & $\frac{c d c 30-1}{c d c 30-3}$ & $12 \cdot 6 \pm 2 \cdot 0$ & $10 \cdot 0 \pm 0 \cdot 5$ \\
\hline WD3 & $\frac{c d c 30-3}{C D C 30-3}$ & $55 \cdot 3 \pm 3 \cdot 1$ & $52 \cdot 3 \pm 3 \cdot 4$ \\
\hline WD4 & $\frac{C D C 30}{C D C 30}$ & $72 \cdot 2 \pm 0 \cdot 35$ & $54 \cdot 2 \pm 3 \cdot 4$ \\
\hline WD6 & $\frac{c d c 30-1}{c d c 30-3}$ & $20 \cdot 5 \pm 0 \cdot 5$ & $24 \cdot 2 \pm 0 \cdot 85$ \\
\hline
\end{tabular}

(Dickinson \& Williams, 1986) and thirdly, because pgil homozygous diploids are asporogenous on potassium acetate (Aguilera, 1986).

After preincubation at $36.5^{\circ} \mathrm{C}$ the wild-type (WD4) and $c d c 30$ heterozygous diploids (WD1 and WD3) sporulated equally well compared with the homozygous diploids (WD2 and WD6) which had significantly reduced sporulation (Table 4). Thus it seems that $c d c 30$ mutations do affect sporulation and hence one might conclude that cell cycle blockade prior to transfer to sporulation medium was the reason for this. Notice, however, that in the case of WD2 and WD6 there was almost no difference between sporulation after preincubation at $25^{\circ} \mathrm{C}$ or $36.5^{\circ} \mathrm{C}$. In other words, the $c d c 30$ mutation is temperature-sensitive with respect to the cell cycle but absolute with respect to sporulation. Our explanation for this is that $S$. cerevisiae requires PGI to be able to complete the gluconeogenic events of sporulation. In $c d c 30$-bearing strains grown glycolytically the activity of this enzyme is reduced to about two-thirds of the level in the wildtype, even at $25^{\circ} \mathrm{C}$ (Dickinson \& Williams, 1987). Furthermore, under the gluconeogenic conditions of acetate utilization that are involved in sporulation PGI activity is further reduced (Maitra \& Lobo, 1971), presumably in $c d c 30$ homozygous diploids to the point where the flux of carbon into glucose 6-phosphate is inadequate.

It is interesting to note that Southern analysis has revealed only one copy of the $P G I I$ gene per haploid genome in $S$. cerevisiae (Aguilera \& Zimmermann, 1986). The analogous experiment will be possible with the cloned $C D C 30$ gene. If the PGII and CDC30 genes do not have significant nucleotide homology this raises the interesting possibility that the isoenzymes of PGI are an example of convergent evolution at the molecular level.

There will undoubtedly be further interest in PGI beyond its role as an essential catalyst in a major metabolic pathway due to the very recent reports that the neurotrophic factor neuroleukin is actually PGI (Chaput et al., 1988; Faik et al., 1988). The availability of the cloned yeast PGII gene facilitated this discovery (Faik et al., 1988). It might be that there is also a mammalian homologue of $C D C 30$.

We are grateful to J. Pringle for strain JPT99 and thank P. Gacesa for the use of isoelectric focussing equipment, R. Caswell for assistance with gels, J. Wimpenny for help with gel scanning and H. Cheetham for photography.

\section{REFERENCES}

AGuilera, A. (1986). Deletion of the phosphoglucose isomerase structural gene makes growth and sporulation glucose dependent in Saccharomyces cerevisiae. Molecular and General Genetics 204, 310-316.
Aguilera, A. \& ZimmermanN, F. K. (1986). Isolation and molecular analysis of the phosphoglucose isomerase structural gene of Saccharomyces cerevisiae. Molecular and General Genetics 202, 83-89. 
Barker, D. G., Johnson, A. L. \& Johnston, L. H. (1985). An improved assay for DNA ligase reveals temperature-sensitive activity in $c d c 9$ mutants of Saccharomyces cerevisiae. Molecular and General Genetics 200, 458-462.

Blakesley, R. W. \& Boezi, J. A. (1977). A new staining technique for proteins in polyacrylamide gels using Coomassie Brilliant Blue G250. Analytical Biochemistry 82, 580-582.

Casperson, G. F., Walker, N. \& Bourne, H. R. (1985). Isolation of the gene encoding adenylate cyclase in Saccharomyces cerevisiae. Proceedings of the National Academy of Sciences of the United States of America 82, 5060-5063.

Caswell, R. C., Gacesa, P. \& Weightman, A. J. (1986). Detection of alginate lyases by isoelectric focusing and activity staining. International Journal of Biological Macromolecules 8, 337-341.

Chaput, M., Claes, V., Portelle, D., Cludts, I., Cravador, A., Burny, A., Gras, H. \& Tartar, A. (1988). The neurotrophic factor neuroleukin is $90 \%$ homologous with phosphohexose isomerase. Nature, London 332, 454-455.

Ciriacy, M. \& Breitenbach, I. (1979). Physiological effects of seven different blocks in glycolysis in Saccharomyces cerevisiae. Journal of Bacteriology 139 , 152-160.

Clifton, D., Weinstock, S. B. \& Fraenkel, D. (1978). Glycolysis mutants in Saccharomyces cerevisiae. Genetics 88, 1-11.

Dickinson, J. R. \& Williams, A. S. (1986). A genetic and biochemical analysis of the role of gluconeogenesis in sporulation of Saccharomyces cerevisiae. Journal of General Microbiology 132, 2605-2610.

Dickinson, J. R. \& Williams, A. S. (1987). The $c d c 30$ mutation in Saccharomyces cerevisiae results in a temperature-sensitive isoenzyme of phosphoglucose isomerase. Journal of General Microbiology 133, 35-140.

Esposito, R. E. \& KLAPHoltz, S. (1981). Meiosis and ascospore development. In The Molecular Biology of the Yeast Saccharomyces, vol. 1, Life Cycle and Inheritance, pp. 211-287. N. Strathern, E. W. Jones \& J. R. Broach. Cold Spring Harbor, NY: Cold Spring Harbor Laboratory.

Faik, P., Walker, J. I. H., Redmill, A. A. M. \& Morgan, M. J. (1988). Mouse glucose-6-phosphate isomerase and neuroleukin have identical $3^{\prime}$ sequences. Nature, London 332, 455-456.

GAME, J. C. (1976). Yeast cell cycle mutant $c d c 21$ is a temperature-sensitive thymidylate auxotroph. Molecular and General Genetics 146, 313-315.

Herrera, L. S. \& Pascual, C. (1978). Genetical and biochemical studies of glucosephosphate isomerase deficient mutants in Saccharomyces cerevisiae. Journal of General Microbiology 108, 305-310.

JoHNSTON, L. H. \& NASMYTH, K. A. (1978). Saccharomyces cerevisiae cell cycle mutant $c d c 9$ is defective in DNA ligase. Nature, London 274, 891-893.

Jong, A. Y. S., Kuo C. L. \& CAMPBell, J. L. (1984). The $C D C 8$ gene of yeast encodes thymidylate kinase.
Journal of Biological Chemistry 259, 1052-1059.

KAWASAKI, G. H. (1979). Karyotypic instability and carbon source effects in cell cycle mutants of Saccharomyces cerevisiae. PhD thesis, University of Washington, Seattle, USA.

Kempe, T. D., Nakagawa, Y. \& Noltmann, E. A. $(1974 a)$. Physical and chemical properties of yeast phosphoglucose isomerase isoenzymes. Journal of Biological Chemistry 249, 4617-4624.

Kempe, T. D., GeE, D. M. \& Noltmann, E. A. $(1974 b)$. Subunit and peptide compositions of yeast phosphoglucose isomerase isoenzymes. Journal of Biological Chemistry 249, 4625-4633.

MaITRA, P. K. (1971). Glucose and fructose metabolism in a phosphoglucoseisomeraseless mutant of Saccharomyces cerevisiae. Journal of Bacteriology 107 , 759-769.

Maitra, P. K. \& Lobo, Z. (1971). A kinetic study of glycolytic enzyme synthesis in yeast. Journal of Biological Chemistry 246, 475-488.

MaITRA, P. K. \& LoBo, Z. (1977). Genetic studies with a phosphoglucose isomerase mutant of Saccharomyces cerevisiae. Molecular and General Genetics 156, $55-60$.

Mason, P., Jacquemin, J. M. \& Culot, M. (1984). Molecular cloning of the $t s m 0185$ gene responsible for adenylate cyclase activity in Saccharomyces cerevisiae. Annales de microbiologie 135A, 343351.

Mortimer, R. K. \& Hawthorne, D. C. (1975). Genetic mapping in yeast. Methods in Cell Biology 11, 221-233.

Nakagawa, Y. \& Noltmann, E. A. (1967). Multiple forms of yeast phosphoglucose isomerase. 1. Resolution of the crystalline enzyme into three isoenzymes. Journal of Biological Chemistry 242, 4782-4788.

Patterson, M., Sclafani, R. A., Fangman, W. L. \& ROSAMOND, J. (1986). Molecular characterisation of the cell cycle gene $C D C 7$ from Saccharomyces cerevisiae. Molecular and Cellular Biology 6, 15901598.

Pringle, J. R. \& Hartwell, L. H. (1981). The Saccharomyces cerevisiae cell cycle. In The Molecular Biology of the Yeast Saccharomyces, vol. 1, Life Cycle and Inheritance, pp. 97-142. Edited by J. N. Strathern, E. W. Jones \& J. R. Broach. Cold Spring Harbor, NY: Cold Spring Harbor Laboratory.

ReEd, S. I., HADWiger, J. A. \& Lorincz, A. T. (1985). Protein kinase activity associated with the product of the yeast cell division cycle gene. CDC28. Proceedings of the National Academy of Sciences of the United States of America 82, 4055-4059.

SClafani, R. A. \& FANGMan, W. L. (1984). Yeast gene $C D C 8$ encodes thymidylate kinase and is complemented by herpes thymidine kinase gene $T K$. Proceedings of the National Academy of Sciences of the United States of America 81, 5821-5825.

SHERMAN, F. (1975). Use of micromanipulators in yeast studies. Methods in Cell Biology 11, 189-199.

SimCHEN, G. (1974). Are mitotic functions required in meiosis? Genetics 76, 745-753. 